\title{
Antitumoral Activity of Slime-forming, Encapsulated Lctococcus lactis subsp. cremoris isolated from Scandinavian Ropy Sour Milk, "viili"
}

\author{
Haruki Kitazawa, Takahiro Toba, Takatoshi ItoH, \\ Nobuko Kumano*, Susumu ADACHI** \\ and Takahiro Y AMAGUCHI ${ }^{* * *}$ \\ Laboratory of Animal Products Chemistry, Faculty of Agriculture, \\ Tohoku University, Aoba-ku, Sendai-shi 981 \\ * The Research Institute for Tuberculosis and Cancer, \\ Tohoku University, Aoba-ku, Sendai-shi 981 \\ ** Shokei Women's Junior College, Natori-shi 981-12 \\ *** Laboratory of Animal Morphology, Faculty of Agriculture, \\ Tohoku University, Aoba-ku, Sendai-shi 981, Japan
}

(Received August 27, 1990)

\begin{abstract}
This study was conducted to investigate the antitumor activity of slimeforming encapsulated Lactococcus lactis subsp. cremoris KVS20 (L. cremoris KVS 20) isolated from Scandinavian ropy sour milk, "viili". Intraperitoneal (i.p.) injection of lyophilized $L$. cremoris KVS 20 cells resulted in the growth inhibition of ascitic and solid tumors of Sarcoma-180 (S-180) in ICR mice. Tumor growth was significantly retarded, and the weight mean survival time significantly increased when the preparation was injected at a dose of $50 \mathrm{mg} / \mathrm{kg}$ for 9 successive days from the day after tumor inoculation. On the other hand, L. cremoris KVS 20 did not exhibit direct cytotoxicity against S-180 tumor cells. These findings suggest that the effectiveness of $L$. cremoris KVS 20 in preventing tumor growth is induced through enhanced host-mediated immunity.
\end{abstract}

Anim. Sci. Technol. (Jpn.) 62 (3) : 277-283, 1991

Key words : ropy sour milk, Lactococcus lactis subsp. cremoris, antitumor activity, host-mediated immunity

Recently, it has been reported that non slime forming dairy lactic lactococci have exhibited antitumor activity against transplantable tumors in mice ${ }^{8)}$. Previous work in our laboratory demonstrated that the lyophilized preparation of Scandinavian ropy sour milk, produced using a starter culture containing slime forming encapsulated lactococci, reduced the number of Lewis lung carcinoma in C 57 $\mathrm{BL} / 6$ mice $^{93}$ and inhibited the growth of the Sarcoma-180 (S-180) solid tumor in ICR mice ${ }^{10)}$. The maximum inhibition of tumor growth was obtained via Finnish ropy sour milk, "viili". In addition, the preparation restored the delayed type hypersensitivity response in mice which was lowered by bearing tumor ${ }^{9)}$. On the other hand, milk components did not show any activities. These findings strongly suggest that some kinds of lactic lactococci in ropy sour milk, "viili" may have preventive potential against tumor growth.

The present study was designed to find out if 
Kitazawa, Toba, Itoh, Kumano, Adachi and Yamaguchi

microorganisms present in "viili" would prevent the growth of the S-180 tumor in ICR mice. The major microorganism in "viili" which has a strong slime-forming nature was isolated and the antitumor properties were evaluted.

\section{Materials and Methods}

Mice

Pathogen free male ICR mice aged 5 weeks $(24 \pm 1 \mathrm{~g})$ were procured from Charles River Japan, Inc, Atsugi, Kanagawa, Japan.

Tumor

Sarcoma-180 (S-180) adapted to ICR mice was obtained from Cancer Cell Repository, Research Institute for Tuberculosis and Cancer, Tohoku University, Sendai, Japan. The tumor was maintained in ascitic form by serial intraperitoneal transfer.

In these experiments, the mice received $1 \times$ $10^{6}$ tumor cells in $0.1 \mathrm{~m} l$ of saline. The tumor cells were injected intraperitoneally (i.p.) in ascitic form and intradermally (i.d.) in solid form for the ascitic and solid experimental systems, respectively.

Isolation and identification of slime-forming encapsulated lactococcus lactis subsp. cremoris KVS 20

The agar medium $(\mathrm{pH} 6.8)$ for isolation of slime-forming lactococcus was prepared by mixing with $5 \mathrm{~g}$ of trypticasepeptone $\left(\mathrm{BBL}^{\mathrm{R}}\right)$, $5 \mathrm{~g}$ of agar (Oxoid, Agar No. 1) and $490 \mathrm{ml}$ of permeate obtained by dialysis of $20 \%(\mathrm{w} / \mathrm{v})$ reconstituted skim milk against the same volume of water (abbreviated as DWA agar medium). Different dilution of "viili" (Valio, Finland) was spread on the DWA agar medium and incubated at $20^{\circ} \mathrm{C}$ for 3 to 6 days under anaerobic conditions. A strong slime-forming colony was taken and purified by transfering on an another DWA plate containing kabicidin (Wako Pure Chem., Co., Ltd., Tokyo, Japan).
Taxonomic properties of the slime-forming Lactococcus subsp. were examined according to the methods of HARrigan et al. ${ }^{6)}$. The test strain was classified to be a ropy variant of $L$. cremoris and numbered KVS 20 according to the results summarized in Table 1 . This strain seems to be the same strain isolated from "viili" by FORSÉN et al. ${ }^{3}$, because of analogy in the taxonomic properties. L. cremoris KVS 20 was cultured in the DWA medium without agar at $18-20^{\circ} \mathrm{C}$ for $24 \mathrm{~h}$, harvented by centrifugation $(15,428 \times \mathrm{g}, 30 \mathrm{~min})$, washed with sterile distilled water and lyophilized. The lyophilyzed cell yield was about $550 \mathrm{mg}$ per $\left(4.36 \times 10^{7}\right.$ cells $\left./ \mathrm{mg}\right)$. The cells were killed by heating in them a saline suspension at $100^{\circ} \mathrm{C}$ for $15 \mathrm{~min}$ prior to use.

Antitumor activity of slime-forming encapsulated L. cremoris KVS 20

The lyophilized preparations of "villi" and $L$. cremoris KVS 20 were injected i.p. daily at a concentration of 10 and $50 \mathrm{mg} / \mathrm{kg}$ for 9 successive days starting on the day after tumor inoculation. The controls were injected with sterile saline and reconstituted skim milk. For tumor growth in ascitic form, a weight mean survival time $\left(\right.$ WMST) ${ }^{1}$ was determined through the experimental period of 45 days. In the solid tumor experiment, the tumors were excised and weighed on the 21st day of the tumor inoculation. The percent inhibition of tumor growth (TGI) was calculated by the formula,

TGI $(\%)=(1-$ mean tumor weight of experiments/mean tumor weight of controls) $\times 100$

Direct cytotoxicity to tumor cells by $L$. cremoris KVS 20

Approximately $1 \times 10^{5}$ tumor cells were suspended in $1 \mathrm{~m} l$ of MEM medium supplemented with $2 \%$ fetal calf serum and were cocultured with various concentrations of the lyophilized $L$. cremoris KVS 20 cells in 24 well 
Antitumoral Activity of L. cremoris

Table 1. Properties of ropy strain KVS 20 isolated from ropy sour milk, "villi"

\begin{tabular}{|c|c|c|c|c|}
\hline \multirow{2}{*}{ Biochemical tests } & \multirow{2}{*}{$\frac{\text { Ropy strain }}{\text { KVS } 20}$} & \multicolumn{3}{|c|}{ Reference strains } \\
\hline & & GIFU $8591^{\mathrm{T} 1}$ & $\mathrm{NCDO} 176^{2}$ & GIFU $8590^{\mathrm{Tl}}$ \\
\hline \multicolumn{5}{|l|}{ Growth at } \\
\hline $10.0^{\circ} \mathrm{C}$ & +3 & + & + & + \\
\hline 39.5 & -4 & + & + & - \\
\hline 45.0 & - & - & - & - \\
\hline \multicolumn{5}{|l|}{ Growth in } \\
\hline $2 \% \mathrm{NaCl}$ & +3 & + & + & + \\
\hline 4 & -4 & + & + & - \\
\hline 6.5 & - & - & - & - \\
\hline $\begin{array}{l}\text { Hydrolysis } \\
\text { of arginine }\end{array}$ & -5 & +6 & + & - \\
\hline Growth at $\mathrm{pH} 9.2$ & -4 & +3 & + & - \\
\hline $\mathrm{CO}_{2}$ from citrate & -7 & - & + & - \\
\hline $\begin{array}{l}\mathrm{CO}_{2} \text { from glucose } \\
\text { fermentation }\end{array}$ & -7 & - & - & - \\
\hline $\begin{array}{l}\text { Type of lactic acid } \\
\text { formed }\end{array}$ & $L(+)$ & $L(+)$ & $\mathrm{L}(++)$ & $\begin{array}{l}\mathrm{L}(+) \\
\text { L. cremoris }\end{array}$ \\
\hline Identification & L. cremoris & L. lactis & L. diacetilactis & \\
\hline
\end{tabular}

${ }^{1}$ GIFU $8591^{\mathrm{T}}(=\mathrm{NCDO} 604$, L. lactis $)$ and GIFU $8590^{\mathrm{T}}(=$ NCDO 607 , L. cremoris $)$ were obtained from Laboratory of Microbiology, Faculty of Medicine, Gifu University.

${ }^{2} \mathrm{NCDO} 176$ ( $L$. diacetilactis) was obtained from AFRC Institute of Food Research, Reading Laboratory, Shinfield, Reading, England.

${ }^{3}$ Growth, as recorded by absorbance $\geqq 0.27$ at $520 \mathrm{~nm}$.

${ }^{4}$ No growth, as recorded by absorbance at $520 \mathrm{~nm}$.

${ }^{5}$ No ammonia production from arginine.

${ }^{6}$ Ammonia production from arginine.

${ }^{7}$ No gas production.

plate (MS-80240, SUMILON, Sumitomo Bakelite Co., Ltd., Tokyo, Japan). After 24, 48 and $72 \mathrm{~h}$, the growth was evaluated by the number of viable cells which were measured by the dye exclusion method of trypan blue ${ }^{12)}$.

\section{Statistics}

Mean tumor weight and survival time were determined by the Student's $t$ test. The difference in the number of survivors was calculated by $\mathrm{x}^{2}$ test.

\section{Results}

Preliminary studies had shown that S-180 have a doubling time of $24 \mathrm{~h}$ as an ascites in ICR mice. All mice died progressively with growing of the tumor after an injection of $10^{6}$ cells. The WMST was $9.7 \pm 2.9$ days after an injection of $10^{6}$ cells.

In the ascitic tumor experiments, different doses of $L$. cremoris KVS 20 in relation with "viili" were used to inhibit the tumor growth. Fig. 1 shows the representative time course of survivors, indicating that the mice treated with $L$. cremoris KVS 20 and viili survived longer than those treated with skim milk and untreated controls. However, no differences were found between $L$. cremoris KVS 20 and viili treatment. The data in Table 2 revealed that the WMST of mice given $L$. cremoris KVS 20 had significantly increased as compared with that of the controls. The degree of increased WMST was not significantly different with the doses administered and was almost the same as 


\section{KitazaWa, TOBA, ItoH, Kumano, ADACHI and Yamaguchi}

those in the case of treatment with viili. Thus, it appears that $L$. cremoris KVS 20 has the ability to inhibit ascitic S-180 tumor in vivo.

Further experiments were performed to confirm the antitumor effects of $L$. cremoris

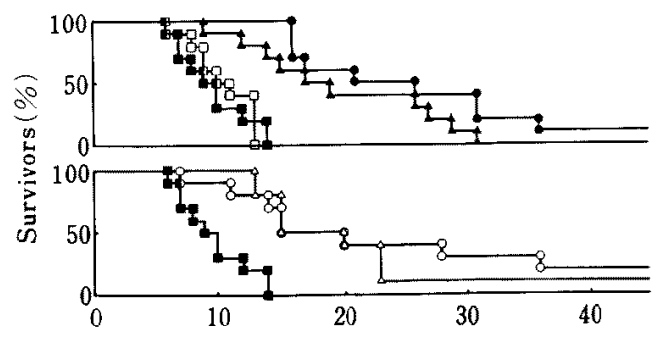

Days after tumor inoculation

Fig. 1. Antitumor activity of $L$. cremoris KVS 20 cells on ascitic S-180 tumor in mice.

- - - Control (saline), $\square-\square$; Skim milk powder $(50 \mathrm{mg} / \mathrm{kg}),-$; Lyophilized viili $(10 \mathrm{mg} / \mathrm{kg}), \boldsymbol{\Delta}-\boldsymbol{\Delta} ;$ Lyophilized viili (50 $\mathrm{mg} / \mathrm{kg}), 0-0 ; L$. cremoris KVS 20 cells $(10 \mathrm{mg} / \mathrm{kg}), \triangle \longrightarrow \triangle ;$ L. cremoris KVS 20 cells $(50 \mathrm{mg} / \mathrm{kg})$.
KVS 20 in the solid tumor system since significant effect had been observed in the ascitic tumor system. The solid tumors were palpable after 5 days of tumor inoculation. Initial growth of the tumors in the mice administered with $L$. cremoris KVS 20 and the control was almost identical. On the 21 st day of tumor inoculation, all animals bearing palpable tumors were sacrificed and their tumors were removed and weighed. Mice given L. cremoris KVS 20 demonstrated inhibition of tumor growth as compared to untreated mice (Table 3). In particular in those mice administered with a dose of $50 \mathrm{mg} / \mathrm{kg}$ of $L$, cremoris KVS 20 , the mean tumor weight was $0.78 \mathrm{~g}$ which is significantly lower than the untreated control mice which bore tumors with a mean weight of $1.51 \mathrm{~g}$. The results indicate that $L$. cremoris KVS 20 has the ability to inhibit the growth of both ascitic and solid S-180 tumors.

The direct cytotoxicity of $L$. cremoris KVS 20 against $\mathrm{S}-180$ tumor cells was evaluated by their co-culture in vitro for $72 \mathrm{~h}$. Results are

Table 2. Antitumor activity of $L$. cremoris KVS 20 cells on ascitic S-180 tumor in mice

\begin{tabular}{lccc}
\hline \hline Group & $\begin{array}{c}\text { Dose } \\
(\mathrm{mg} / \mathrm{kg})\end{array}$ & $\begin{array}{c}\text { WMST } \\
\text { (days, mean } \pm \mathrm{S} . \mathrm{D} .)\end{array}$ & $\begin{array}{c}\text { No of survivors } \\
\text { for 45 days }\end{array}$ \\
\hline Control & (saline) & $9.7 \pm 2.9$ & 0 \\
Skim milk powder & 50 & $10.6 \pm 2.6$ & 0 \\
Lyophilized viili & 10 & $19.9 \pm 7.8^{*}$ & 0 \\
KVS 20 cells & 50 & $25.0 \pm 9.1^{*}$ & 1 \\
& 10 & $20.5 \pm 9.6^{*}$ & 1 \\
\hline
\end{tabular}

Groups were consisted of 10 mice.

${ }^{*} \mathrm{p}<0.05$ (against Control).

Table 3. Antitumor activity of $L$. cremoris KVS 20 cells on solid S-180 tumor in mice

\begin{tabular}{lcccc}
\hline \hline Group & $\begin{array}{c}\text { Dose } \\
(\mathrm{mg} / \mathrm{kg})\end{array}$ & $\begin{array}{c}\text { Tumor } \\
\text { incidence }\end{array}$ & $\begin{array}{c}\text { Tumor weight } \\
(\mathrm{g}, \text { mean } \pm \mathrm{S} . \mathrm{D} .)\end{array}$ & $\begin{array}{c}\text { TGI } \\
(\%)\end{array}$ \\
\hline Control & $($ saline $)$ & $10 / 10$ & $1.51 \pm 0.73$ & 0 \\
KVS20 cells & 10 & $10 / 10$ & $1.02 \pm 0.44$ & 32.1 \\
& 50 & $10 / 10$ & $0.78 \pm 0.58^{*}$ & 48.2 \\
\hline
\end{tabular}

${ }^{*} p<0.05$ (against Control). 


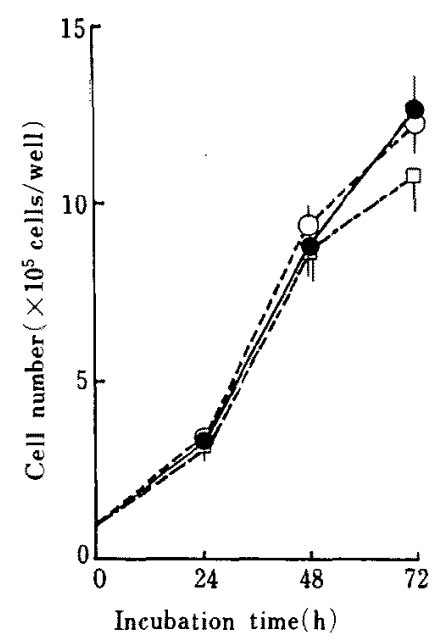

Fig. 2. Direct cytotoxic activity of $L$. cremoris KVS 20 cells on S-180 tumor.

- Control (saline), $0-0 ; 100 \mu \mathrm{g} / \mathrm{ml}$, ; $500 \mu \mathrm{g} / \mathrm{m} l$.

shown in Fig. 2. L. cremoris KVS 20 failed to inhibit the growth of the $\mathrm{S}-180$ tumor cells at a concentration of $100 \mu \mathrm{g} / \mathrm{ml}$. At a high concentration of $500 \mu \mathrm{g} / \mathrm{ml}$, the number of tumor cells was slightly suppressed, but it was not significantly lower than that of the control. Thus, L. cremoris KVS 20 is shown to have no direct killing potential against S-180 tumor cells.

\section{Discussion}

The slime-forming lactic acid bacteria isolated from ropy sour milk viili was identified to be $L$. cremoris. This is in conformity with the view that the characteristic ropiness of viili is produced by encapsulated species of $L$. cremoris $^{13)}$. The heat killed L. cremoris KVS 20 cells showed significant inhibition activity against the growth of the $\mathrm{S}-180$ tumor. This fact suggest that $L$. cremoris KVS 20 cells are the primary component in viili which is potential to prevent the development of S-180 tumor. Since the injection of ropy sour milks in previous studies with the same schedules has shown a reduced number of Lewis lung carcinoma ${ }^{9)}$ and to inhibit the growth of S-180 tumor $^{10)}$, in this experiments, L. cremoris KVS 20 cells were injected i.p. for 9 successive days from the day after tumor inoculation. The highest prevention of tumor growth via $L$. cremoris KVS 20 was achieved when it was injected at a concentration of $50 \mathrm{mg} / \mathrm{kg}$ in both forms of ascitic and solid tumors, and the incidence of the effect on both forms of S-180 tumors was almost the same. Thus, L. cremoris KVS 20 is effective not only for ascitic but also for solid tumors inoculated in the distant part from the injection site of $L$. cremoris KVS 20 , indicating that the antitumor effect of $L$. cremoris KVS 20 may be induced by the indirect host reaction enhanced with $L$. cremoris KVS 20 injection. Several researchers have recognized the antitumor activity of dairy lactic acid bacteria against allogenic and syngenic tumors in mice ${ }^{2,4,6,7,8,11,14,16)}$. In particular, Lactobacillus casei (L. casei) has exhibited marked antitumor activity against the ascitic and solid forms of S-180 when it was injected i.p. and intravenously at a concentration of 2 and $10 \mathrm{mg} / \mathrm{kg}$ for 5 days after tumor inoculation $^{7)}$. It appears that the potential of $L$. cremoris KVS 20 to inhibit the growth of the S-180 tumor is comparable to that of $L$. casei although detailed experiments on the effective doses and administration route are to be done.

L. cremoris KVS 20 had no direct cytotoxicity against S-180 tumor cells in vitro, indicating that the antitumor activity of $L$. cremoris KVS 20 is not dependent on direct growth inhibition. It is known that various microorganisms have an immunostimulating effect which is involved in their antitumor activity. The mechanism by which $L$. cremoris KVS 20 can inhibit tumor growth remains unclear. One of the advanced conceivable mechanism appears to be an enhancement of the immune responses of the host.

It has been demonstrated that a polysaccharide produced by Lactobacillus helveticus 


\section{Kitazawa, Toba, Itoh, Kumano, Adachi and Yamaguchi}

var. jugurti $i^{15)}$, component (s) synthesized by a yoghurt starter culture ${ }^{4)}$ and glycopeptide cell wall fragments of Lactobacillus delbrueckii subsp. bulgaricus ${ }^{2)}$ induces the growth inhibition of tumors. The slime material produced by $L$. cremoris KVS 20 may also be a principal component in the antitumor factor in "viili".

\section{References}

1) Baze, W.B., E. Lovovsky, G.A. Higbee, H.B. LeyY and D.E. Hilmas, Evalution of a nuclease derivative of Poly (I). Poly (c) [Poly (ICLC)] as a radioprotective agent. Radiation Res., 77 : 276-284. 1979.

2) Bogdanov, I.G., P.G. Dalev, A.I. Gurevich, M.N. Kolosov, V.P. Malkova, L.A. Plemyannikova and I.B. Sorokina, Antitumor glycopeptides from Lactobacillus bulgaricus cell wall. FEBS Letters, 57 : 259-261. 1975.

3) Forsen, R., N. Raunio and R. Myllymaa, Studies on slime forming group $\mathrm{N}$ streptococcus strains I. Acta Univ. Oul. A 12, Biochem. 3 : 1-19. 1973.

4) Friend, B.A., R.E. FARMer and K.M. SHAHANI, Effect of feeding and intraperitoneal implantation of yoghurt culture cells on Ehrlich ascites tumor. Milchwissenschaft, 37 : 708-710. 1982.

5) Goldin, B.R. and S.L. Gorbach, Effect of Lactobacillus acidophilus dietary supplements on 1,2-dimetylhydrazine dihydrochloride- induced intestinal cancer in rats. J. Natl. Cancer Inst., 64 : 263-265, 1980.

6) Harrigan, W.F., E. Margaret and M.E. MC Cane, Laboratory Methods in Food and Dairy Microbiology. Academic Press. New York. 1976.

7) Kato, I., S. Kobayashi, T. Yokokura and M. Mutai, Antitumor activity of Lactoba- cillus casei in mice. Jpn. J. Cancer Res. (GANN), 72: 517-523. 1981.

8) Kelkar, S.M., M.A. Shenoy and G.S. KAKLIJ, Antitumor activity of lactic acid bacteria on a solid fibrosarcoma, Sarcoma-180 and Ehrlich ascites carcinoma. Cancer Letters, 42: 73-77. 1988.

9) Kitazawa, H., T. Toba, T. Iтоh, S. Adachi and N. Kumano, Effect of ropy sour milk on the metastasis of Lewis lung carcinoma in mice. Agric. Biol. Chem., 52 : 2331-2332. 1988.

10) Kitazawa, H., T. Toba, T. Itoh, N. Kumano and S. ADACHI, Antitumor activity of ropy sour milks in murine solid tumor. Jpn. J. Zootech. Sci., 61 : 1033-1039. 1990.

11) KohwI, Y., K. ImaI, Z. Tamura and $Y$. Hashimoto, Antitumor effect of Bifidobacterium infantis in mice. Jpn. J. Cancer Res. (GANN), 69: 613-618. 1978.

12) Kruse, P.F.J. and M.K.J. Patterson eds. Tissue culture: Methods and applications. Academic Press. New York. 1973.

13) Marshall, V.M., Fermented milks and their future trends. I. Microbiological aspects. J. Dairy Res., 54 : 559-574. 1987.

14) Matsuzaki, T., T. Yokokura and $\mathrm{I}$. Azuma, Antitumor activity of Lactobacillus casei on Lewis lung carcinoma and line-10 hepatoma in syngeneic mice and guinea pigs. Cancer Immunol Immunother., $20: 18-22.1985$.

15) Oda, M., H. Hasegawa, S. Komatsu, M. KAMBe and F. Tsuchiya, Antitumor polysaccharide from Lactobacillus sp. Agric. Biol. Chem., $47:$ 1623-1625. 1983.

16) Yasutake, N., I. Kato, M. Ohwaki, T. Yokokura and M. MutaI, Host-mediated antitumor activity of Lactobacillus casei in mice. Jpn. J. Cancer Res. (GANN), 75 : 72-80. 1984. 
スカンジナビアの粘質酸乳“ヴィリー”より分離した莢膜性粘質 物産生 Lactococcus lactis subsp. cremoris の抗腫瘍活性

\author{
北澤春樹・戸羽隆宏・伊藤敞敏・熊野伸子* \\ 足立 達** $\cdot$ 山口高弘 \\ 東北大学農学部，仙台市青葉区 981 \\ *東北大学抗酸菌病研究所, 仙台市青葉区 980 \\ ** 尚絧女学院短期大学, 名取市 $981-12$
}

\begin{abstract}
莯腫韵活性を示したスカンジナビアの粘質酸乳“ヴィリー”中の活性成分を検索する目的の一環とし て，ヴィリー上り萊膜性粘質物産生 Lactococcus lactis subsp. cremoris (L. cremoris KVS 20) を分離し，乙の菌体の抗腫湢活性を Sarcoma-180 (S-180) 腹水およで固型腫煌系で検討した，その結

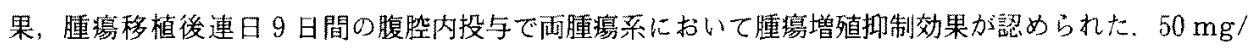
$\mathrm{kg}$ 投与では，腫疸增殖が有意に抑制され，平均生存日数（WMST）が增加した，一方，L. cremoris KVS 20 は in vitroにおいて，S-180 腫瘍細胞に対して直接細胞障害活性を示さなかった。これらの 結果より，L. cremoris KVS 20 の腫瘍增殖抑制效果は宿主免疫の增強を介して禖導される屯のと考 えられた。
\end{abstract}

日音会報，62 (3)：277-283，1991 